\title{
Amount of information transmitted in absolute judgments of pitch calculated according to the majority rule
}

\author{
ANTE FULGOSI, ZVONIMIR KNEZOVIĆ, and PREDRAG ZAREVSKI \\ Odsjek za Psihologiju, Filozofski Fakultet, Zagreb 41000, Yugoslavia
}

\begin{abstract}
Sixteen tones differing in frequencies from $80 \mathrm{~Hz}$ to $4,400 \mathrm{~Hz}$ were presented in random order 100 times each to 15 subjects divided in three experimental groups 15 subjects in each group) for absolute identification. Amount of transmitted information in identification responses and corresponding number of categories were determined on the basis of (1) individual identification responses, represented by the median value of transmission in each group, and (2) the dominant responses of each group to each presented stimulus. It was found that the amount of transmitted information and the corresponding number of categories were always larger in the case of dominant responses (the average increase in the number of identified categories was 38.7\%). Results were interpreted as proof of the influence of random factors in individual identification performance.
\end{abstract}

In classical information-transmission experiments the amount of transmitted information in absolute judgments was calculated from one stimulus by a response matrix containing pooled responses from all subjects in the experiment (Garner, 1962; Pollack, 1952). Fulgosi and Bartolovic (1971) and Fulgosi and Żaja (1975) have shown that such a procedure artificially increases response equivocation and reduces the amount of transmitted information. The same authors have shown that the median value of individually calculated transmission for each subject is a fairer index of transmission and identification abilities.

Exploring further the identification abilities in the situation of absolute judgments, Fulgosi (Note 1) hypothesized that the identification performance of each subject is under the strong influence of unsystematically variable (random) factors. This hypothesis was based on the empirical fact of approximately normal distribution of identification responses in nontrained and trained subjects. The present experiments were conducted to further investigate and test this hypothesis.

If the identification performance is under the control or influence of random processes in each subject, individual responses to stimuli will be less reliable and more equivocal than the dominant responses of all subjects in the group (taken as the identification responses). Calculating the amount of transmitted information on the basis of the dominant responses of the entire group should give values of transmitted information higher than the values obtained from individual responses. Such results may be interpreted as a confirmation of our hypothesis of random processes influencing identification performance, corroborating some of our earlier results (Fulgosi, Lugomer, Knezović, \& Zarevski, 1980).

In the present investigation, three experiments were conducted in which tones differing in frequencies were presented to subjects for identification. In each experiment, the amount of transmitted information was calculated for each subject in the group on the basis of his individual identification responses and was compared with the information transmitted by the dominant responses of the entire group.

\section{METHOD}

\section{Subjects}

Five subjects were included in each of the three groups (Groups A, B, C). Inclusion in a particular group was on a random basis. All subjects were students of psychology with normal hearing abilities.

\section{Apparatus}

Tones of different frequencies were generated by an RC generator (Type MA 3604) that was connected to five Koss earphones.

\section{Stimuli}

Tones were selected on the basis of Licklider's (1950) graph of loudness of tones of different frequencies to represent tones of approximately the same loudness. The following 16 tones were presented in each experiment: $80,120,160,220,300,400$, $500,700,1,000,1,500,1,800,2,400,3,000,3,400,4,000$, and $4,400 \mathrm{~Hz}$.

\section{Procedure}

The experiments were conducted in a sound-supressed room. Stimuli were presented in the same random order for all three groups. Each stimulus was presented for $4 \mathrm{sec}$. The interstimulus interval was $8 \mathrm{sec}$. During the experiment, each tone was presented 100 times. Each experiment was divided into $20 \mathrm{seg}$ ments. In each segment, each tone was presented five times.

In the first 10 segments (first half of each experiment), after each identification response, subjects were given the feedback information (the right identification response). In the second 10 segments (second half of each experiment), no feedback was given. 
Subjects were told that their task was to identify each tone with the proper number (from 1 to 16 ). Number 1 was used for identification of the lowest $(80-\mathrm{Hz})$ tone.

Subjects worked individually. The dominant response for each stimulus was found later from such individual responses.

Each experiment was conducted for 5 consecutive days. Each day, four segments of stimuli were presented to subjects, which makes 320 stimuli in each session. After the first two segments in each session, subjects were given a pause of $5 \mathrm{~min}$.

Before each experimental session, the experimenter presented all tones from the lowest to the highest and gave the right identification number for each one. Before the first session, subjects were given a short training session comprising 32 stimuli.

To keep the motivation of subjects high, after each segment subjects were informed about the number of right identifications of each participant in the group in that segment.

\section{RESULTS}

Individual information transmission indexes were calculated in each group, and the median value of these five indexes was determined. Besides this, information transmission for each group was calculated on the basis of the dominant responses of the group to each presented stimulus. Only values for the second half of the experiment are shown (Table 1).

Information transmission in terms of categories that correspond to the median and the dominant responses (amounts of transmitted information) are shown in Table 2.

\section{DISCUSSION}

Obtained transmission values show that in each experimental group (Groups A, B, C), amount of transmitted information when the dominant responses of the group are taken as the identification responses is substantially larger than the amount of information obtained on the basis of individual responses of each member of the group. The average value of the increase in the number of identified categories for all three groups is $38.7 \%$. The amount of information contained in the dominant responses in each group was larger than even the largest individual amount of information.

Such results seem to corroborate our hypothesis that unsytematically variable factors in subjects are the cause of at least one part of the equivocation in absolute identification. Controlling such random processes by taking the dominant response of the entire group as the identification response eliminates a
Table 1

Amount of Transmitted Information (in Bits)

\begin{tabular}{|c|c|c|c|}
\hline Group & \multicolumn{2}{|c|}{$\begin{array}{l}\text { Median of Individual } \\
\text { Transmission Indexes }\end{array}$} & $\begin{array}{l}\text { Dominant Response } \\
\text { of the Group }\end{array}$ \\
\hline A & \multicolumn{2}{|c|}{2.74} & 3.09 \\
\hline B & \multicolumn{2}{|c|}{2.33} & 2.88 \\
\hline $\mathrm{C}$ & \multicolumn{2}{|c|}{2.33} & 2.84 \\
\hline \multicolumn{4}{|c|}{$\begin{array}{c}\text { Table 2 } \\
\text { Number of Identified Categories }\end{array}$} \\
\hline Group & MI & DR & PI \\
\hline A & 6.7 & 8.5 & 27.4 \\
\hline B & 5.0 & 7.4 & 46.3 \\
\hline $\mathrm{C}$ & 5.0 & 7.2 & 42.3 \\
\hline
\end{tabular}

Note $-M I=$ median of individual transmission indexes; $D R=$ dominant response of the group; $P I=$ percent increase.

part of such unsystematic influences and, consequently, increases the amount of information contained in the identification responses of the group as a whole.

\section{REFERENCE NOTE}

1. Fulgosi, A. The random factor in absolute judgments. Unpublished manuscript, 1978.

\section{REFERENCES}

Fulgosi, A., \& Bartolovic, B. Practice and some methodological problems in unidimensional information transmission. Perception \& Psychophysics, 1971, 10, 283-285.

Fulgosi, A., Lugomer, G., Knezović, Z., \& Zarevski, P. Količina prenesene informacije kod apsolutnih sudova oredjena po načelu vecine. Stručni skup psihologa, Zagreb, 1980.

Fulgosi, A., \& ŽAJA, B. Information transmission of 3.1 bits in absolute identification of auditory pitch. Bulletin of the Psychonomic Society, 1975, 6, 379-380.

GaRner, W. R. Uncertainty and structure as psychological concepts. New York: Wiley, 1962.

LickLIDER, J. C. R. Basic correlates of the auditory stimulus. In S. S. Stevens (Ed.), Handbook of experimental psychology. New York: Wiley, 1950.

Pollack, I. The information of elementary auditory displays. Journal of the Acoustical Society of America, 1952, 24, 745. 749.

(Received for publication January 17, 1983.) 